\title{
Effect of IAA and GA3 toward the growing and saponin content of purwaceng (Pimpinella alpina)
}

\author{
DASIYEM FATHONAH ${ }^{1, \boldsymbol{v}}$, SUGIYARTO ${ }^{2}$ \\ ${ }^{1}$ SMA Negeri 1 Sapuran, Jl. Purworejo Km. 20 Sapuran, Wonosobo 56373, Jawa Tengah, Indonesia. Tel/Fax.: +92-286-611173, `email: \\ sma1sapuran@yahoo.co.id \\ ${ }^{2}$ Bioscience Program, School of Graduates, Sebelas Maret University, Surakarta 57126, Central Java, Indonesia
}

Manuscript received: 23 December 2008. Revision accepted: 4 February 2009

\begin{abstract}
Fathonah D, Sugiyarto. 2009. Effect of IAA and GA3 toward the growing and saponin content of purwaceng (Pimpinella alpina). Nusantara Bioscience 1: 17-22. The aims of this research are to examine (i) the effect of IAA and GA3 in different concentrations on the growth of the plants and (ii) the saponin contained inside the P. alpina leaves. The research was done in Sikunang Village, Kejajar Subdistrict, Wonosobo District, Central Java, from July to November 2007. The Completely Random Design used the experimental methods with two factors to analyze this experiment. The first treatment gives IAA and GA 3 ; the second provides different IAA and $\mathrm{GA}_{3}$ concentrations. These experiments were repeated three times. Variables measured in this research were plant growth consisting of the number of leaves, their height, width, wet weight, and dry weight. The chemical compound of the secondary metabolite in the form of leave saponin was employed. Analysis of Variance (ANOVA) analyzed the result, then continued to Duncan Multiple Range Test in 5\% level to analyze the real difference between those treatments. The result showed that giving IAA and GA 3 differently affects the growth of $P$. alpina. In variable of the height, the optimal wet weight and dry weight in $\mathrm{GA}_{3}$ treatment was 50 ppm; an optimum number of leaves in $\mathrm{GA}_{3}$ treatment was $50 \mathrm{ppm}$, whereas the leaves width in IAA treatment was 200 ppm and $\mathrm{GA}_{3}$ treatment was $75 \mathrm{ppm}$. Optimum saponin treatment was IAA $200 \mathrm{ppm}$ and $\mathrm{GA}_{3} 25 \mathrm{ppm}$.
\end{abstract}

Keywords: Pimpinella alpina, IAA, GA, growth, saponin, Dieng.

\begin{abstract}
Abstrak. Fathonah D, Sugiyarto. 2009. Pengaruh IAA dan GA3 terhadap pertumbuhan dan kandungan saponin purwaceng (Pimpinella alpina). Nusantara Bioscience 1: 17-22. Tujuan penelitian ini adalah untuk mengkaji (i) pengaruh IAA dan GA dengan konsentrasi yang berbeda untuk pertumbuhan tanaman dan (ii) saponin yang terkandung di dalam daun Pimpinella alpina. Penelitian dilakukan di Desa Sikunang, Kecamatan Kejajar, Kabupaten Wonosobo, Jawa Tengah pada Juli-November 2007. Metode percobaan menggunakan Rancangan Acak Lengkap dengan dua faktor digunakan untuk menganalisis percobaan ini. Pertama memberikan perlakuan IAA dan $\mathrm{GA}_{3}$, kedua memberikan perlakuan IAA dan GA3 dengan konsentrasi berbeda. Percobaan diulang tiga kali. Variabel yang diukur adalah pertumbuhan tanaman yang terdiri dari jumlah daun, tinggi tanaman, lebar daun, berat basah maupun berat kering; serta senyawa kimia metabolit sekunder dalam bentuk saponin. Hasil penelitian ditelaah dengan Analisis Varian (ANAVA), kemudian dilanjutkan ke Uji Jarak Berganda Duncan pada tingkat 5\% untuk mengetahui perbedaan nyata antara perlakuan. Hasil penelitian menunjukkan bahwa pemberian IAA dan $\mathrm{GA}_{3}$ yang berbeda mempengaruhi pertumbuhan $P$. alpina. Pada variabel tinggi, berat basah dan berat kering tanaman perlakuan $\mathrm{GA}_{3}$ yang optimal adalah $50 \mathrm{ppm}$, jumlah daun optimal dalam perlakuan $\mathrm{GA}_{3}$ adalah 50 ppm dimana lebar daun optimal pada perlakuan IAA adalah 200 ppm dan pada perlakuan GA3 adalah 75 ppm, sedangkan kadar saponin optimal adalah perlakuan IAA 200 ppm dan $\mathrm{GA}_{3} 25 \mathrm{ppm}$.
\end{abstract}

Kata kunci: Pimpinella alpina, IAA, GA, pertumbuhan, saponin, Dieng.

\section{INTRODUCTION}

Lately, traditional medicinal plants have become popular and are wanted by modern society (the city) because it is believed that traditional medicines' effects are relatively small compared to modern medicines. But one of the weaknesses of traditional medicine is not much information about their chemical constituents and compounds, which is responsible for biological activity. Traditional medicine is medicine where the ingredients are derived from nature, either from plant, animal, or mineral materials $\mathrm{MoH}$ 1981). Purwaceng or purwoceng (Pimpinella alpina Molk.; previously named Pimpinella pruatjan Molk.) is one of the plants which has a property as a traditional medicine that its natural existence is already scarce in Dieng Plateau, its natural habitat, along with the loss of protected forest in the region as a result of the uncontrolled forest encroachment activities by the local community. In Wonosobo District, purwaceng is naturally found only in the Villages of Sikunang, Siterus and Dieng, District of Kejajar. According to Rahardjo (2003) and Shaheed et al. (2004), these plants exist only on a very narrow cultivation area in Sikunang Village, no longer found in their natural habitat. Basically, this plant can grow in any area in the Dieng Plateau and be planted anytime during the dry season even though it does not rain for a long time because it needs no watering as much as in potato cultivation. The morphology of $P$. alpina is illustrated in Figure 1. 


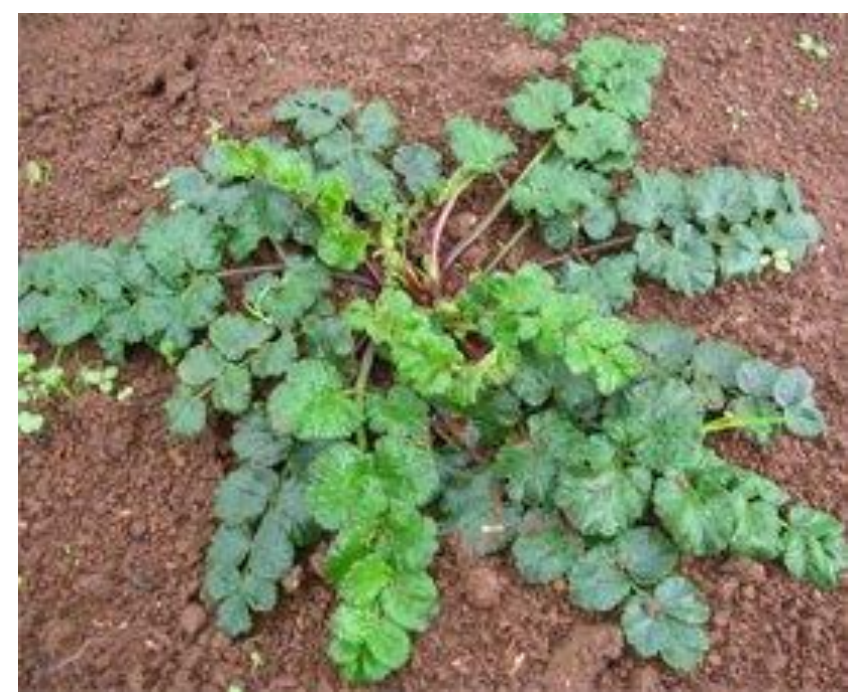

Figure 1. Morphology of $P$. alpina

Purwoceng, as a medicinal plant, contains active compounds which give the effect of warmth on the body and increase emotion. This crude drug has been known as a sexual desire arousing (aphrodisiac) and urine laxative drug (diuretic) (Astuti 2005). Purwaceng contains major phytochemical groups of alkaloids, polyphenols, flavonoids, and saponins. Bergapten, isobergapten, and sphondin belong to the group of furanocoumarin (Sidik et al. 1975), also coumarins, saponins, sterols, alkaloids, and several kinds of sugar compounds ( oligosaccharide) (Caropeboka and Lopez 1975), stigmasterol (Suzery et al. (2004), bergapten, marmesin, 4-hydroxycoumarin, umbelliferone, and psoralen (Hernani and Rostiana (2004).

Saponins have many roles on healthy plants; it functions as an anti-fungal (Zehavi et al. 1993; Bowyer et al. 1995) and anti-virus (Wu et al. 2007). Saponins also have significant anti-microbial effects (Papadopoulou et al. 1999). These molecules also act to overcome a heart attack. Some saponins are also a functional cure against virus attacks (Zao et al., 2008). Commercially, saponins inhibit tumor cell growth and lower blood cholesterol (Ridker 2005). Low cholesterol on blood serum of East African people, who consume food products of animal which have many fat and cholesterol, because it is counterbalanced by eating the herb-rich with saponins (Oleszek and Marston 2000; Davidson 2004).

Looking at the potential of saponin, which is so much in helping the body's physiologic functions, would require further research on the chemical content of saponins in Purwaceng plants. Because purwaceng are plants with low flexibility in terms of adaptation, it is necessary to cultivate purwaceng crops by manipulating the environment to obtain optimal results. Optimal environmental factors are expected to increase purwaceng growth and the chemical content of secondary metabolites, so purwaceng production is expected to boost economic value for people who cultivate it.

According to Salisbury and Ross (1995), high light intensity increases carotenoid content and nitrogen content, making the leaf surface more open. Still, on the other hand, the exceptionally high light intensity can reduce leaf chlorophyll content. Some of the knowledge required in the cultivation technique is related to factors of light, knowledge of plants, spacing, and crop cover use.

In addition to its fast-growing, Purwaceng is managed to contain higher secondary metabolites, one with the application of growth regulators. Growth regulator (PGR), known as plant hormones (phytohormones), is the "regulator" produced by the plant itself, and at low levels, it regulates plant biochemical, physiological, and morphological processes. Therefore, the effort to improve crop yields of purwaceng is necessary with the use of PGR, so it is expected that it will be more optimal for growing Purwaceng as well as increasing the content of chemical compounds. This study examines how IAA and $\mathrm{GA}_{3}$ affect the growing and the saponin content of plant leaves of Purwaceng and how to influence the interaction of IAA and $\mathrm{GA}_{3}$ on increasing the saponin content of plant leaves Purwaceng.

\section{MATERIALS AND METHODS}

\section{Plant material}

Materials used in this study are obtained from Purwaceng plants from Dieng Plateau on the border of Wonosobo and Banjarnegara Districts, Central Java Province.

\section{Procedures}

Experiments are conducted using Completely Randomized Design (CRD), the first factor in the form of IAA and $\mathrm{GA}_{3}$, and the second factor is the concentration of IAA and $\mathrm{GA}_{3}$, which are performed differently for three repetitions, including the number of leaves, plant's height, leaf's area, fresh weight, dry weight, while the secondary metabolites of saponin content of leaves and analyzed using analysis of variance (ANOVA) followed by Duncan's Multiple Range Test (DMRT) at 5\% test level to find out the fundamental differences among the treatments.

Seeding. The seeding is started from the manufacture of growing media and site preparation on seedling plots of land measuring $100 \mathrm{~cm}$ x $400 \mathrm{~cm}$ plus compost with a ratio of 3: 1 under protective cover/shelter. Seeding process is started by selecting a good seed that is not broken and of the same size. Sowing seeds is in the morning and the early of sowing seeding, the watering is done once in 2 days until the plants are six weeks old and ready to be moved into poly bags.

Table 1. The experimental design

\begin{tabular}{lcccc}
\hline \multirow{2}{*}{$\begin{array}{c}\text { Concentration } \\
\text { of IAA (A) }\end{array}$} & \multicolumn{4}{c}{ Concentration of $\mathbf{G A}_{\mathbf{3}}(\mathbf{B})$} \\
\cline { 2 - 5 } & $\mathbf{0} \mathbf{~ p p m}$ & $\mathbf{2 5} \mathbf{~ p p m}$ & $\mathbf{5 0} \mathbf{~ p p m}$ & $\mathbf{7 5} \mathbf{~ p p m}$ \\
$\left(\mathbf{B}_{\mathbf{0}}\right)$ & $\left(\mathbf{B}_{\mathbf{1}}\right)$ & $\left.\mathbf{B}_{\mathbf{2}}\right)$ & $\left(\mathbf{B}_{\mathbf{3}}\right)$ \\
\hline $0 \mathrm{ppm}\left(\mathrm{A}_{0}\right)$ & $\mathrm{A}_{0} \mathrm{~B}_{0}$ & $\mathrm{~A}_{0} \mathrm{~B}_{1}$ & $\mathrm{~A}_{0} \mathrm{~B}_{2}$ & $\mathrm{~A}_{0} \mathrm{~B}_{3}$ \\
$100 \mathrm{ppm}\left(\mathrm{A}_{1}\right)$ & $\mathrm{A}_{1} \mathrm{~B}_{0}$ & $\mathrm{~A}_{1} \mathrm{~B}_{1}$ & $\mathrm{~A}_{1} \mathrm{~B}_{2}$ & $\mathrm{~A}_{1} \mathrm{~B}_{3}$ \\
$200 \mathrm{ppm}\left(\mathrm{A}_{2}\right)$ & $\mathrm{A}_{2} \mathrm{~B}_{0}$ & $\mathrm{~A}_{2} \mathrm{~B}_{1}$ & $\mathrm{~A}_{2} \mathrm{~B}_{2}$ & $\mathrm{~A}_{2} \mathrm{~B}_{3}$ \\
$300 \mathrm{ppm}\left(\mathrm{A}_{3}\right)$ & $\mathrm{A}_{3} \mathrm{~B}_{0}$ & $\mathrm{~A}_{3} \mathrm{~B}_{1}$ & $\mathrm{~A}_{3} \mathrm{~B}_{2}$ & $\mathrm{~A}_{3} \mathrm{~B}_{3}$ \\
\hline
\end{tabular}


Planting. Planting is done when seeds are six weeks old on the planting medium, i.e., poly bag measuring $9 \mathrm{~cm} \times 15$ $\mathrm{cm}$ and filled with soil and compost with a ratio of $3: 1$. At this stage, watering is done every three days.

Treatment. Treatment begins after the age of 4 weeks of planting. Treatment includes: spraying IAA and $\mathrm{GA}_{3}$ in combination with appropriate design of experiments on plants at 10 weeks of age for eight weeks with eight times spraying for 1 week at $09.00 \mathrm{am}$. Treatments include: controlling plants, spraying of IAA concentration of $0 \mathrm{ppm}$, $100 \mathrm{ppm} 200 \mathrm{ppm}$, and $300 \mathrm{ppm}$ at different polybags, spraying of $\mathrm{GA}_{3}$ concentration of $25 \mathrm{ppm}, 50 \mathrm{ppm}, 75 \mathrm{ppm}$, also at separate polybags. Each spraying is done as much as 5 $\mathrm{ml}$ with five times spraying with the same pressure.

Observations. The variables measured in the observations included leaf number obtained by counting all the existing leaves on the plant, plant's height measured from the base of the stem (leaf midrib) to the tallest part of plants, the leaf was calculated with the gravimetric method (Sitompul and Guritno 1995) which is formulated as follows:

$$
\begin{aligned}
L D & =W r \times \frac{L K}{W t} \\
\mathrm{LD} & =\text { leaf's area } \\
\mathrm{Wr} & =\text { weight of paper leaf replica } \\
\mathrm{Wt} & =\text { total weight of paper } \\
\mathrm{Lk} & =\text { total area of paper }
\end{aligned}
$$

The following variable is the wet weight of plants that are weighed with an analytical balance, dry weight of plants which is calculated by, first, the plants are harvested and immediately measured and placed in a paper bag and then roasted at a temperature of $60^{\circ} \mathrm{C}$ for five days to achieve constant dry weight, then weighed by analytical scales. Then the leaf saponin content analysis is conducted after harvest (plants are two months old) with the UVspectrophotometric method with following steps, first, in the extraction phase, the dry leaves are crushed with a mortar till they become powder, then 0.1 grams of powder of them are extracted with 10 milliliters of ethanol $70 \%$ above the water steam bath with a temperature of $80^{\circ} \mathrm{C}$ for 15 minutes, then, the phase of making a standard curve that is made by Merck Saponin standard solution with concentration $2.5,5.0,7.5,10 \mathrm{ppm}$ and then the absorbance is measured using UV-Vis spectrophotometer at a wavelength of $365 \mathrm{~nm}$ to obtain a standard curve of saponin (Stahl 1985). In the phase of counting saponin content of the leaves, extracted leaves are calculated their saponin levels using a UV-Vis spectrophotometer based on the standard curve of saponin Merck. The levels obtained then is converted into $\mathrm{mg} / \mathrm{g}$ dry weight of leaves (Suskendriyati et al. 2004) with the following formula:

$$
\begin{aligned}
& \mathrm{S}=\frac{\text { Saponin content of sample } \mathrm{x} \text { volume of dilution }}{\text { Sample weigh of leaves }} \\
& \mathrm{S}=\text { concentration of saponin }
\end{aligned}
$$

\section{RESULTS AND DISCUSSION}

\section{Plant growth}

According to Abidin, a plant growth regulator or hormone regulates plant physiological processes (1994) because hormones can affect protein synthesis and regulation of enzyme activity. Increased protein synthesis as raw material constituent enzymes in plant metabolic processes would enhance growth. This process can improve future growth can increase the biosynthesis of secondary metabolites (Taiz and Zeiger 2006).

Plant growth is influenced by several factors, including external and internal factors. Internal factors that influence growth include auxin (IAA) and gibberellin $\left(\mathrm{GA}_{3}\right)$. Some effects of hormones on plant cell growth were as follows: the stimulating effect on the growth hormone was highly inhibited by the actinomyosin D antibiotic. This substance uses its influence on the cell precisely, i.e., by binding the DNA nucleus and preventing the two DNA bands to split up so that DNA cannot be used as a mold for manufacturing, whether additional DNA molecules or RNA molecules. Without additional new RNA, protein synthesis by the cells freezes quickly (Kimball 1991). This understanding can be based on exogenous hormone use with a specific concentration to stimulate or inhibit growth. Gene activity begins with the transcription of DNA into mRNA. mRNA comes out from the nucleus to the cytosol and is translated at the ribosomes, resulting in protein synthesis. Protein synthesis forms new enzymes and activates certain enzymes that affect metabolism. A series of metabolic processes will affect plant growth (Salisbury and Ross 1995).

The study's growing variable includes the number of leaves, leaf area, plant height, wet weight, dry weight, and saponin content. The Treatment with various concentrations of IAA in this study is given to 3-month-old purwaceng plants until they reach young harvest time, namely at the age of 5 months. The results are shown in Table 2 .

\section{Number of leaves}

Based on Table 2, it is known that the treatment will give real effect at a concentration of IAA $0 \mathrm{ppm} \mathrm{GA}_{3} 50$ ppm. The overall provision of IAA, $\mathrm{GA}_{3}$, or a combination of IAA and $\mathrm{GA}_{3}$, will increase the number of leaves, except at a concentration of IAA $300 \mathrm{ppm} \mathrm{GA}_{3} 0 \mathrm{ppm}$. It is possible because the provision of growth hormone IAA 300 ppm would hamper growth. The experiment of Noggle and Fritz (1983) shows that exogenous IAA plays a role in inhibiting the mother leaves bone. Then the inhibition of mother leaves bone formation will also inhibit the formation of the leaf itself.

\section{Leaf's area}

The leaf is one of the growth parameters observed due to environmental changes. A change in the leaf is very sensitive to environmental changes. Leaf growth is closely associated with water availability in the environment. The development of the leaves is very. 
Table 2. The plant growth of $P$. alpina with the IAA and $\mathrm{GA}_{3}$ treatment

\begin{tabular}{|c|c|c|c|c|}
\hline \multirow{2}{*}{$\begin{array}{l}\text { Concentration of } \\
\text { IAA (ppm) }\end{array}$} & \multicolumn{4}{|c|}{ Concentration of $\mathrm{GA}_{3}(\mathrm{ppm})$} \\
\hline & $\mathbf{0}$ & 25 & 50 & 75 \\
\hline \multicolumn{5}{|l|}{ Number of leaves } \\
\hline 0 & $7.67^{\mathrm{a}}$ & $9,00^{\mathrm{cd}}$ & $10,33^{\mathrm{e}}$ & $8,67^{\mathrm{cd}}$ \\
\hline 100 & $9.67^{\mathrm{de}}$ & $9,00^{\mathrm{cd}}$ & $8,67^{\mathrm{cd}}$ & $8,00^{b c}$ \\
\hline 200 & $8.67^{\mathrm{cd}}$ & $9,00^{\mathrm{cd}}$ & $9,67^{\mathrm{de}}$ & $9,67^{\mathrm{de}}$ \\
\hline 300 & $7.00^{\mathrm{ab}}$ & $8,33^{\mathrm{bc}}$ & $8,33^{b c}$ & $8,00^{b c}$ \\
\hline \multicolumn{5}{|l|}{ Plant leaf's area } \\
\hline 0 & $24.20^{\text {be }}$ & $21,60^{\mathrm{bc}}$ & $27,60^{\mathrm{f}}$ & $26,40^{\mathrm{eg}}$ \\
\hline 100 & $24.80^{\mathrm{bf}}$ & $25,20^{\mathrm{cf}}$ & $27,60^{\mathrm{f}}$ & $26,60^{\mathrm{ef}}$ \\
\hline 200 & $25.40^{\mathrm{df}}$ & $22,40^{\text {bd }}$ & $24,60^{\mathrm{bf}}$ & $31,40^{\mathrm{g}}$ \\
\hline 300 & $19.00^{\mathrm{a}}$ & $22,00^{\mathrm{bc}}$ & $26,40^{\mathrm{ef}}$ & $22,40 b^{d}$ \\
\hline \multicolumn{5}{|l|}{ Plant's height } \\
\hline 0 & $12.00^{\mathrm{ab}}$ & $14,33^{\mathrm{cd}}$ & $20,50^{\mathrm{e}}$ & $15,00^{\mathrm{de}}$ \\
\hline 100 & $15.17^{\mathrm{dc}}$ & $12,17^{\text {de }}$ & $15,83^{\mathrm{d}}$ & $11,83^{\mathrm{ab}}$ \\
\hline 200 & $16.67^{\mathrm{c}}$ & $15,33^{\mathrm{d}}$ & $13,83^{\text {ce }}$ & $16,00^{\text {de }}$ \\
\hline 300 & $10.83^{\mathrm{a}}$ & $11,83^{\mathrm{a}}$ & $11,67^{\mathrm{ab}}$ & $12,67^{\mathrm{ac}}$ \\
\hline \multicolumn{5}{|l|}{ Plant's fresh weight } \\
\hline 0 & $2.57^{\mathrm{a}}$ & $4,12^{\mathrm{gh}}$ & $5,82^{\mathrm{i}}$ & $3,88^{\mathrm{fg}}$ \\
\hline 100 & $2.92^{\mathrm{ac}}$ & $3,60^{\mathrm{ef}}$ & $4,27^{\mathrm{h}}$ & $2,93^{\mathrm{ac}}$ \\
\hline 200 & $2.77^{\mathrm{ab}}$ & $2,77^{\mathrm{ab}}$ & $3,35^{\mathrm{de}}$ & $3,91^{\mathrm{fg}}$ \\
\hline 300 & $2.63^{\mathrm{a}}$ & $3,25^{\mathrm{ee}}$ & $3,26^{\mathrm{ce}}$ & $3,10^{\text {bd }}$ \\
\hline \multicolumn{5}{|l|}{ Plant's dry weight } \\
\hline 0 & $0.38^{\mathrm{ab}}$ & $0,53^{\mathrm{eg}}$ & $0,74^{j}$ & $0,51^{\mathrm{e}}$ \\
\hline 100 & $0.49^{\mathrm{dc}}$ & $0,55^{\text {fh }}$ & $0,57^{\mathrm{gi}}$ & $0,52^{\mathrm{eg}}$ \\
\hline 200 & $0.41^{b c}$ & $0,62^{\mathrm{i}}$ & $0,42^{\mathrm{bc}}$ & $0,59^{\mathrm{hi}}$ \\
\hline 300 & $0.35^{\mathrm{a}}$ & $0,40^{\mathrm{ac}}$ & $0,43^{\mathrm{bc}}$ & $0,45^{\mathrm{cd}}$ \\
\hline \multicolumn{5}{|c|}{ The saponin content of plant } \\
\hline 0 & $9.59^{\mathrm{e}}$ & $8,92^{\mathrm{bc}}$ & $8,92^{\mathrm{bc}}$ & $8,78^{\mathrm{b}}$ \\
\hline 100 & $9.28^{\mathrm{d}}$ & $8,54^{\mathrm{a}}$ & $11,16^{\mathrm{j}}$ & $10,68^{\mathrm{h}}$ \\
\hline 200 & $9.05^{\mathrm{c}}$ & $12,00^{1}$ & $10,83^{\mathrm{i}}$ & $10,54^{\mathrm{g}}$ \\
\hline 300 & $8.93^{b}$ & $11,53^{\mathrm{k}}$ & $10,85^{\mathrm{i}}$ & $10,38^{\mathrm{f}}$ \\
\hline
\end{tabular}

sensitive to environmental changes and growth hormones, either exogenous or endogenous. The following table shows the results of studies of leaf area of $P$. alpina plant on different IAA and $\mathrm{GA}_{3}$ treatment. By providing a combination of IAA and $\mathrm{GA}_{3}$, it is expected to have a positive effect on changes in the leaf's area. Table 2 notes that the treatment combination of IAA and $\mathrm{GA}_{3}$ significantly influences the leaf's area. The highest leaf area is at the treatment of IAA 200 ppm $\mathrm{GA}_{3} 75 \mathrm{ppm}$, so the capacity indicates that it is the best response of the optimal growth of the leaf's area compared to other treatments. At the treatment of IAA 300 ppm GA 25 ppm, the leaves area are, in average, at least number, this shows that to this treatment, the plant's response for exogenous hormones has the character of inhibiting the growth of leaves area.

\section{Plant's height}

The plant's height is very sensitive to water availability in the soil. Plant height is the parameter most frequently observed to measure the influence of the environment
(Sitompul and Guritno 1995). Treatment of plant cells with auxin causes an increase not only in the synthesis of RNA but also in protein synthesis. At first, applying synthetic gibberellin to plant cells leads to the explosion of RNA synthesis, followed by a synthesis of various hydrolytic enzymes (Kimball 1999). These activities encourage good growth processes of roots, stems, and leaves. The following table shows the research results on the plant's height of $P$. alpina on different IAA and $\mathrm{GA}_{3}$ treatments. From Table 4, it is noted that the combination treatment of IAA and $\mathrm{GA}_{3}$ significantly influences the plant's height. The average plant's height is seen in combination IAA 0 ppm $\mathrm{GA}_{3} 50$ ppm. This shows that this combination is the best treatment for variable height. By giving IAA $300 \mathrm{ppm} \mathrm{GA}_{3} 0 \mathrm{ppm}$, the lowest plant's height is created; this is possible that in such combinations, there is negative feedback so that the plant suffered intrauterine growth retardation.

\section{Plant fresh weight}

All synthetic plant hormones or compounds with physiological and biochemical properties similar to plant hormones are plant growth regulators (plant growth regulator substances). Plant hormones and plant growth regulators, in general, encourage growth and development occur. The plant growth regulator (PGR) effect depends on plant species, the PGR site of action on plants, plant growth stage, and concentration of PGR. One PGR does not work alone in influencing the growth and development of plants. In general, the equilibrium of concentration of some PGR will control the growth and development of plants (Kusumo 1989). It is noted in Table 2 that the treatment combination of IAA and $\mathrm{GA}_{3}$ significantly influences the fresh weight of plants. The lowest fresh weight is obtained in the combination treatment of IAA 0 ppm $\mathrm{GA}_{3} 0 \mathrm{ppm}$. The highest fresh weight occurs in IAA treatment $0 \mathrm{ppm}$ $\mathrm{GA}_{3} 50 \mathrm{ppm}$. This means that the plant growth regulator provided at that concentration optimally affects the growth of almost all aspects of growing except the leaf's area growth.

\section{Dry weight of plant}

A plant's dry weight depends on cells' speed capability to divide, enlarge and elongate. The speed of cell activity can be influenced by the growth of hormones such as auxin and cytokinin endogenous. Adding some exogenous growth hormone is expected to accelerate the growth process. Auxin affects stem length increment, growth, differentiation, and branching roots. While providing gibberellins promotes bud development, stem elongation, and leaf growth, influencing growth and differentiation are also roots, plant dry weight of $P$. alpina. Table 2 notes that the treatment combination of IAA and $\mathrm{GA}_{3}$ significantly affects plant dry weight. The highest plant dry weight was obtained at treatment combinations of IAA $0 \mathrm{ppm} \mathrm{GA}_{3} 50$ ppm; this indicates that the combination is optimal growth. The lowest dry weight contained in the IAA treatment was $300 \mathrm{ppm} \mathrm{GA}_{3} 0 \mathrm{ppm}$. This shows that the combination treatment does not occur in optimal growth due to metabolic disorders. 
Saponin content in leaf

Secondary metabolites in plant cells accumulate in different amounts. Secondary metabolism contributes to survival, one of which was in self-defense (Manito 1992). Saponin is one class of terpenoid secondary metabolites synthesized through the acid path mevalonate of respiration. From Table 2, it is noted that the combination treatment of IAA and $\mathrm{GA}_{3}$ has a significant influence on levels of leaf saponins. The highest saponin content present in the treatment of IAA $200 \mathrm{ppm} \mathrm{GA}_{3} 25 \mathrm{ppm}$ and saponin content of the lowest in the treatment of IAA $100 \mathrm{ppm} \mathrm{GA}_{3}$ $25 \mathrm{ppm}$.

\section{Discussion}

The results of this study show giving ZPT on the various treatments had a significant effect on the growth and saponin content of plant $P$. alpina. The following table calculates each crop's average dry weight and saponin content in each treatment (Table 3).

\section{The effect of IAA}

IAA at a $100-200 \mathrm{ppm}$ concentration affects various growth parameters, including leaf number, plant height, leaf area, and plant fresh weight. Giving IAA at low concentrations of $100 \mathrm{ppm}$ gives a real difference to the number of leaves formed. The number of leaves is strongly influenced by genetic factors (Goldworthy and Fisher 1992). In this experiment, 300 ppm IAA treatment produces the least number of leaves, although no significant difference with control plants. The higher concentration of IAA is given, the fewer leaves are formed.

Based on the research, the treatment will have a real effect on the leaf's area at a concentration of 200 ppm IAA, although not significantly different from a concentration of $100 \mathrm{ppm}$. In the $300 \mathrm{ppm}$ IAA provision, the plant's height is low, although not significantly different from control plants. The provision of IAA, which is not optimal, will inhibit the growth of the plant itself (Hopkins 1999).

Table 3. Average dry weight calculations and saponin content of each crop in each treatment

\begin{tabular}{|c|c|c|c|}
\hline $\begin{array}{l}\text { Treatment } \\
(\text { ppm) }\end{array}$ & Dry weight & $\begin{array}{c}\text { Saponin } \\
\text { content }(\mathrm{mg} / \mathrm{g})\end{array}$ & $\begin{array}{c}\text { Saponin content } \\
\text { of each plant }\end{array}$ \\
\hline IAA $0+\mathrm{GA}_{3} 0$ & 0.35 & 9.59 & 3.36 \\
\hline IAA $100+\mathrm{GA}_{3} 0$ & 0.49 & 9.28 & $4.55^{* *}$ \\
\hline IAA $200+\mathrm{GA}_{3} 0$ & 0.41 & 9.05 & 3.71 \\
\hline IAA $300+\mathrm{GA}_{3} 0$ & 0.38 & 8.93 & 3.39 \\
\hline IAA $0+\mathrm{GA}_{3} 25$ & 0.53 & 8.92 & 4.23 \\
\hline IAA $0+\mathrm{GA}_{3} 50$ & 0.74 & 8.85 & $6.55 * *$ \\
\hline IAA $0+\mathrm{GA}_{3} 75$ & 0.51 & 8.79 & 4.48 \\
\hline IAA $100+\mathrm{GA}_{3} 25$ & 0.55 & 8.54 & 4.70 \\
\hline $\mathrm{IAA} 200+\mathrm{GA}_{3} 25$ & 0.62 & 12.00 & $7.44 * *$ \\
\hline IAA $300+\mathrm{GA}_{3} 25$ & 0.40 & 11.53 & 4.61 \\
\hline $\mathrm{IAA} 100+\mathrm{GA}_{3} 50$ & 0.57 & 11.16 & 6.36 \\
\hline IAA $200+\mathrm{GA}_{3} 50$ & 0.42 & 10.82 & 4.55 \\
\hline $\mathrm{IAA} 300+\mathrm{GA}_{3} 50$ & 0.43 & 10.85 & 4.67 \\
\hline IAA $100+\mathrm{GA}_{3} 75$ & 0.52 & 10.68 & 5.55 \\
\hline $\mathrm{IAA} 200+\mathrm{GA}_{3} 75$ & 0.59 & 10.54 & 6.22 \\
\hline IAA $300+\mathrm{GA}_{3} 75$ & 0.45 & 10.38 & 4.67 \\
\hline
\end{tabular}

Provision of 200 ppm IAA shows the highest number of leaves, although not significantly different from $100 \mathrm{ppm}$ IAA and control. In comparison, the provision of $300 \mathrm{ppm}$ IAA is substantially different from the control. Giving the IAA will increase the leaf's area formed. IAA triggers the formation of mesophyll tissue, so the leaf's area which is formed also increases. The provision of $100 \mathrm{ppm}$ IAA concentration gives the highest fresh weight, although not significantly different from the concentration of $200 \mathrm{ppm}$ IAA treatment. Giving IAA 300 ppm gives no significant difference in wet weight. IAA plays a role in cell elongation, especially in the vertical direction. Elongation will be followed by cell enlargement and increased wet weight. Increased wet weight is mainly due to higher water uptake by these cells (Noggle and Fritz 1983).

Giving IAA concentration of $100 \mathrm{ppm}$ gives a lower weight control; during the provision of $300 \mathrm{ppm}$, IAA is not significantly different from the control. Growth is associated with increasing volume and number of cells, the formation of protoplasm, and the dry weight in subsequent. Drying aims to stop the cellular metabolism of these materials (Sitompul and Guritno 1995). Provision of IAA in plants $P$. alpina has the effect of accelerating growth at a concentration of 100-200 ppm, but not so with the content of saponin. The saponin content in this study is best in the condition without treatment and then followed at a concentration of 100, 200, and 300 ppm.

\section{The effect of $\mathrm{GA}_{3}$}

This study shows that the growth of $P$. alpina is strongly influenced by the provision of $\mathrm{GA}_{3}$. The provision of $\mathrm{GA}_{3}$ within eight weeks impacted the process of growth. From the observed parameters, the provision of $50 \mathrm{ppm}$ $\mathrm{GA}_{3}$ had optimal growing the number of leaves, plant's height, leaf's area, fresh weight, dry weight, and this effect is inversely proportional to the saponin content. The higher concentration of $\mathrm{GA}_{3}$ given, the saponin levels produced decrease. The decrease that occurred in the treatment of 75 ppm is possible because the concentration negatively affects the growth of the primary plant.

Taiz and Zeiger (2006) explain that the provision of high $\mathrm{GA}_{3}$ will cause a decreased transcription of $\mathrm{GA}_{20}$ oxides, a major target in regulating feedback. If transcription of these compounds decreases, there will be a biosynthesis hindrance of $\mathrm{GA}_{3}$ which will cause activation of $\mathrm{GA}_{3}$ to decrease. The results are consistent with Chairani's (1988) reports that the application of concentration of $50 \mathrm{ppm} \mathrm{GA}_{3}$ gives good effect in increasing the biomass of leaves of Mentha piperita plants. At a concentration of $50 \mathrm{ppm}$, dry leaf weight is $56 \%$ higher than the controls. It is different from the research results by Khristyana et al. (2005) that the concentration of 75 ppm $\mathrm{GA}_{3}$ treatment in Plantago major shows a significant difference with control.

Results analysis of variance of plant $P$. alpina shows that $\mathrm{GA}_{3}$ provides significantly different levels of saponins at a level of $5 \%$ in the test. Based on research data, the highest levels of saponin were in control, and the levels decreased along with the increasing concentrations of $\mathrm{GA}_{3}$. $\mathrm{GA}_{3}$ affects nucleic acid metabolism, plays a role in protein 
synthesis, and regulates the activity of enzymes for plant growth. Increased protein synthesis as raw material constituent enzymes in plant metabolic processes may increase the biosynthesis of secondary metabolites, including saponins, later (Martin 1998).

Providing a combination of IAA and $\mathrm{GA}_{3}$ on various treatments significantly affects the growth and saponin content of plant $P$. alpina. This study shows that the growth of $P$. alpina is strongly influenced by a combination of IAA and $\mathrm{GA}_{3}$ treatment. The provision of IAA and $\mathrm{GA}_{3}$ within eight weeks affects the growth process shown on its dry weight at the treatment of IAA 200 ppm GA $_{3} 25$ ppm, although there is no significant difference in the treatment. In general, the combination of IAA and $\mathrm{GA}_{3}$ treatment that will increase the growth can be seen from increasing wet weight and dry weight. The treatment combination of IAA and $\mathrm{GA}_{3}$ enables the influence of IAA and $\mathrm{GA}_{3}$ to be optimal since the IAA is required for maximum effect of $\mathrm{GA}_{3}$ work. The research shows a combination of IAA 200 ppm $\mathrm{GA}_{3} 25 \mathrm{ppm}$ produced the highest saponin content. It means that the treatment combinations had a real influence on the growth and saponin content of the $P$. alpina plant on the concentration of IAA $200 \mathrm{ppm} \mathrm{GA}_{3} 25 \mathrm{ppm}$.

\section{CONCLUSION}

The provision of different plant growth regulators (PGR) affects the growth of $P$. alpina. At the variables of plant's height, leaf number, fresh weight, dry weight, which was optimal at GA3 50 ppm treatment, the optimal leaf's area growth is at the treatment of IAA 200 GA3 75 ppm. At the same time, the saponin content is optimal at the treatment of IAA $200 \mathrm{GA}_{3} 25 \mathrm{ppm}$. The provision of different plant growth regulators affects the leaf saponin content of $P$. alpina. In a single treatment, saponin content is lower than control plants, whereas the treatment combination of IAA $200 \mathrm{GA}_{3} 25$ ppm increases leaf saponin content by $12 \mathrm{mg} / \mathrm{g}$.

\section{REFERENCES}

Abidin. 1994. The Basics Knowledge about Plant Growth Regulators. Penerbit Angkasa. Bandung. [Indonesian]

Astuti Y. 2005. Isolation, Identification, and Toxicity Testing of Methylene Chloride Fraction of Active Compounds from Purwoceng Plants (Pimpinella alpina Molk.) [Thesis S1]. Department of Chemistry, State University of Diponegoro, Semarang. [Indonesian]

Bowyer P, Clarke BR, Lunness P, Daniels MJ, Osbourn AE. 1995. Host range of a plant pathogenic fungus determined by a saponin detoxifying enzyme. Science 267 (5196): 371-374. DOI: 10.1126/science.7824933.

Caropeboka AM, Lubis I. 1975. Preliminary examination of the chemical content of Pimpinella alpina (purwoceng) roots. Symposium on Medicinal Plants I. Section of Pharmacology, Faculty of Veterinary, Bogor Agricultural University, Bogor, 8-9 December 1975. [Indonesian]

Chairani F. 1998. Effect of gibberellic acid phytohormone application to the canopy biomass and partition coefficient of photosynthate peppermint plant. Pemberitaan Penelitian Tanaman Industri 14 (1-2): 28-33. [Indonesian]

Davidson MW. 2008. Saponin. http://micro.magnet.fsu.edu/ phytochemicals/pages/saponin.html

Ministry of Health [MoH]. 1981. Utilization of medicinal plants. 2nd ed. Ministry of Health, GoI. Jakarta. [Indonesian]

Goldsworthy PR, Fisher NM. 1992. Physiology of Tropical Crops. Gajah Mada University Press, Yogyakarta. [Indonesian]

Hernani, Rostiana O. 2004. Chemical analysis of root purwoceng (Pimpinella pruatjan). Seminar on Indonesian Biopharmaca and Exhibition Conference. Yogyakarta, 14-15 July 2004. [Indonesian]

Hopkins WG. 1999. Introduction to Plant Physiology. John Willey and Sons, New York.

Khristyana L, Anggarwulan E, Marsusi 2005. Growth, levels of saponins, and plant tissue nitrogen of Plantago major L. in granting gibberellic acid $\left(\mathrm{GA}_{3}\right)$. Biofarmasi 3 (1): 11-15. DOI: 10.13057/biofar/f030103. [Indonesian]

Kimball JW. 1991. Biology. Penerbit Erlangga, Jakarta. [Indonesian]

Kusumo S. 1989. Plant Growth Regulator. Yasa Guna, Jakarta. [Indonesian]

Manitto, P. 1992. Biosynthesis of Natural Products. IKIP Press, Semarang. [Indonesian]

Martin R. 1998. Protein Synthesis: Methods and Protocols. Humana Press, Totowa, NJ.

Noggle GR, Fritz GJ. 1983. Introductory Plant Physiology. Prentice Hall, New Jersey.

Oleszek W, Marston A. 2000. Saponins in food, feedstuffs, and medicinal plants. Springer, Amsterdam. DOI: 10.1007/978-94-015-9339-7.

Papadopoulou K, Melton R E, Leggeff M, Daniels M J, Osbourn AE. 1999. Compromise disease resistances in saponin-deficient plants. Proc Nat Acad Sci USA 96 (22): 12923-12928. DOI: 10.1073/pnas.96.22.12923.

Ridker PM, Nissen SE, Ehrenstein MR, Smith S Jr. 2005. Blood test could help prevent heart deaths. New England J Med 352: 20-39.

Salisbury FB, Ross CW. 1995. Plant Physiology. Vol. 3. Penerbit ITB. Bandung. [Indonesian]

Sidik, Sasongko, Kurnia E, Ursula. 1975. Coumarin derivatives isolated from roots purwoceng (Pimpinella alpina Molk.) origin of the Dieng plateau. Symposium on Medicinal Plants I. Section of Pharmacology, Faculty of Veterinary, Bogor Agricultural University, Bogor, 8-9 December 1975.

Sitompul SM, Guritno B. 1995. Analysis of Plant Growth. Universitas Gadjah Mada Press, Yogyakarta. [Indonesian]

Stahl E. 1985. Chromatography and Microscopic Analysis of Drug. Penerbit ITB, Bandung. [Indonesian]

Suskendriyati H, Solichatun, Setyawan AD. 2004. Growth and saponin production Talinum paniculatum Gaertn callus cultures. with a variety of carbon sources. Biosmart 6 (1): 19-23. [Indonesian]

Suzery M, Cahyono B, Ngadiwiyana, Nurhasnawati H. 2004. Stigmasterol compounds from Pimpinella alpina Molk. Suplemen 39 (1): 39-41. [Indonesian]

Syahid SF, Rostiana O, Rohmah M. 2004. Effect of NAA and IBA on rooting purwoceng (Pimpinella alpina Molk.) in vitro. Indonesian Biopharmaca Exhibition and Conference. Yogyakarta, 14-15 Juli 2004. [Indonesian]

Taiz L, Zeiger E. 2006. Plant Physiology. 4th ed. Sinauer, Sunderland.

Wu ZJ, Ouyang MA, Wang CZ, Zhang YK, Shen JG. 2007. Anti-Tobacco Mosaic Virus (TMV) triterpenoid saponins from the leaves of Ilex oblonga. J Agric Food Chem 55 (5): 1712-1717. DOI: $10.1021 /$ jf062421r.

Zehavi U, Ziv-Fecht O, Levy L, Naim M, Evron R, Polacheck I. 1993. Synthesis and antifungal activity of medicagenic acid saponins on plant pathogens: modification of the saccharide moiety and the $23 \alpha$ substitution. Carbohydrate Res 244 (1): 161-169. DOI: 10.1016/00086215(93)80012-4.

Zhao Y-L, Cai G-M, Hong X, Shan L-M, Xiao X-H. 2008. Anti-hepatitis $\mathrm{B}$ virus activities of triterpenoid saponin compound from Potentilla anserine L. Intl J Phytother Phytopharmacol 15 (4): 253-258. DOI: 10.1016/j.phymed.2008.01.005 